удК 343.352

\author{
I. Б. Юрчишин \\ orcid.org/0000-0001-6038-725X \\ детектив \\ Національного антикорупційного бюро України, \\ аспірант спещіальної кафедри № 22 \\ Навчально-наукового інституту контррозвідувальної діяльності \\ Національної академї Служби безпеки України
}

\title{
КРИМІНАЛЬНА ВІДПОВІДАЛЬНІСТЬ ЗА НЕЗАКОННЕ ЗБАГАЧЕННЯ: ЗАРУБІЖНИЙ ДОСВІД ПРАВОВОЇ РЕГЛАМЕНТАЦІЇ
}

Нині корупція становить проблему, розв'язання якої для багатьох країн $є$ надзвичайно актуальним питанням. Корупція, безперечно, є загрозою національній безпеці держави, уповільнює її економічний розвиток, що є відчутним бар'єром для надходження іноземних інвестицій, а також нівелює довіру населення до державних органів та органів місцевого самоврядування. Крім того, масштаби корупційних виявів негативно впливають на міжнародний імідж країни.

$\mathrm{y}$ відповідь на поширення корупції держави вдаються до різних, здебільшого інноваційних підходів у сфері кримінально-правової політики з метою забезпечення невідворотності покарання за такий злочин. Одним із таких заходів є криміналізація незаконного збагачення, в основі філософії якого лежить неприйняття практики збільшення статків посадовця, яке не може бути розумно пояснене і яке відбулося під час перебування його чи іiї на посаді [1, с. 4-5].

Як свідчить практика багатьох країн, протидія незаконному збагаченню не обмежується лише закріпленням відповідної статті у кримінальному кодексі. Цілком зрозумілим $є$ те, що для розв'язання цієї проблеми необхідний комплексний підхід, який дасть змогу створити дієвий механізм притягнення винних осіб до відповідальності за цей злочин. Складником такого підходу повинні стати грунтовні наукові дослідження зазначеного інституту, що дозволило б сформувати необхідні теоретичні передумови для подальшої практичної реалізації кримінальної відповідальності. Важливим аспектом таких досліджень $є$ вивчення досвіду зарубіжних країн та врахування його в процесі вдосконалення в нашій державі власного інституту кримінальної відповідальності за незаконне збагачення.

Кримінально-правову характеристику незаконного збагачення досліджували українські науковці Д.О. Гарбазей, О.І. Гузоватий, О.П. Денега, О.О. Дудоров, К.П. Задоя, В.М. Киричко, 0.О. Книженко, М.В. Кочеров, В.Н. Кубальський, М.І. Мельник, В.А. Мисливий, Д.Г. Михайленко, B.О. Навроцький, В.Я. Тацій, Т.М. Тертиченко, P.В. Трофименко, В.I. Тютюгін, М.I. Хавронюк,
О.Ю. Шостко, І.М. Ясінь. Значну увагу дослідженню проблематики незаконного збагачення приділяли і зарубіжні науковці та експерти, серед яких І. Данєлєне, Г. Дордж, Д. Жалімас, Н. Кофеле-Кале, Н. Гачері Камунде, К. Мюллер, Н. Цоцорія.

Попри те, що результати досліджень зазначених науковців мали важливе значення для становлення інституту кримінальної відповідальності за вказаний злочин, а їхні висновки залишаються актуальними й нині, все ж доводиться констатувати, що проблема незаконного збагачення в Україні залишається не досить дослідженою. Це зумовлено й тим, що більшість досліджень зазначених авторів стосувалася статті $368^{2}$ Кримінального кодексу України, яку Рішенням Конституційного Суду № 1-p/2019 від 26.02.2019 визнано такою, що не відповідає Конституції України, а стосовно нової статті $368^{5}$ дослідження ще не $\epsilon$ такими результативними.

Метою статті є дослідження досвіду правової регламентації кримінальної відповідальності в низці зарубіжних країн, виокремлення особливостей і спільних рис, в тому числі й порівняння із законодавством України.

Цілком зрозуміло, що досвід зарубіжних країн не може бути використаний шляхом простого копіювання і запозичення існуючих в цих країнах моделей. Питання в тому, щоб у такому досвіді вичленити ті складники, які могли б бути ефективними в нашій державі з урахуванням особливостей національної правової системи та практики діяльності правоохоронних органів, могли б стати частиною власної правової моделі боротьби 3 незаконним збагаченням.

Загалом ми вважаємо, що протидія незаконному збагаченню включає як мінімум два складники - правовий та організаційний. Правовий також можна поділити на частину, яка регламентує власне кримінальну відповідальність за цей злочин, i ту, яка визначає процедуру розслідування та притягнення до відповідальності за нього. В межах цієї статті ми будемо розглядати лише першу частину. Водночас це абсолютно не означає, що інші є менш важливими. Зовсім ні. Часто 
саме регулювання процесу організації протидії незаконному збагаченню і досвід діяльності в цьому напрямі правоохоронних органів впливають на подальшу зміну регламентації самої відповідальності. Однак ці питання потребують окремого вивчення й можуть стати предметом інших публікацій. Отже, нашу увагу буде приділено основним міжнародним і національним правовим актам, які становлять ядро правової регламентації кримінальної відповідальності за незаконне збагачення.

Розуміння змісту незаконного збагачення як дійсно важливої проблеми почало з'являтися наприкінці 70-х років XX століття. Першою серед міжнародних організацій, яка визначила невідповідність доходів і видатків посадовців займаним посадам, виконуваним функціям як незаконне збагачення і необхідність його криміналізації, стала Організація Американських Держав. У статті 9 Міжамериканської конвенції проти корупції зазначається, що «відповідно до своєї Конституції і основних принципів правової системи кожна Держава-учасниця, яка ще не зробила цього, повинна вжити необхідних заходів для встановлення за своїм законодавством як злочину суттєвого збільшення майна урядового чиновника, якщо він не може зрозуміло пояснити щодо його законних заробітків під час здійснення своїх функцій» [2]. Лише дві (США та Канада) із 33 країн, які підписали та ратифікували Міжамериканську конвенцію проти корупції, відмовилися визнавати як окремий склад злочину «незаконне збагачення» [3].

Докорінно інший підхід до розуміння терміну «незаконне збагачення» містить Конвенція Африканського союзу про недопущення корупції та боротьбу з нею. Згідно зі ст. 1 Конвенції незаконним збагаченням визнається значне збільшення активів не лише державної посадової особи, яке він або вона не може раціонально обгрунтувати щодо його або її доходу, а й будь-якої іншої особи. Тобто у випадку наявності у громадянина майна значно більшого за його офіційні доходи незалежно від належності до державної служби це буде визнаватися актом корупції та вимагатиме відповідного розслідування [4, с. 86].

На відміну від зазначених вище конвенцій, на теренах європейського континенту в рамках Кримінальної конвенції Ради Свропи про боротьбу 3 корупцією, складеної на основі ст. К. 3 (2) (с) Договору про Європейський Союз, яка стосується посадових осіб Європейських Співтовариств або посадових осіб держав-членів Свропейського Союзу, взагалі відсутні будь-які згадки про таке кримінальне діяння як «незаконне збагачення " [4, с. 86].

У 2003 році на загальносвітовому рівні була прийнята Конвенція Організації Об’єднаних Націй проти корупції (далі - Конвенція або Конвенція ООН проти корупції), ст. 20 якої встановлює можливість вжиття таких законодавчих та ін- ших заходів, які можуть бути необхідними для визнання злочином умисного незаконного збагачення, тобто значного збільшення активів державної посадової особи, яке перевищує її законні доходи та які вона не може раціонально обгрунтувати за умови дотримання своєї Конституції та основоположних принципів своєї правової системи [5]. Хоча відповідальність за згаданий злочин існувала в деяких країнах і до прийняття Конвенції, але саме з цього моменту питанню протидії незаконному збагаченню як окремому злочину почали приділяти відповідну увагу у значній частині країн світу.

На національному рівні поняття незаконного збагачення як злочину вперше було введене в Аргентині у 1964 році. Того ж року аналогічне поняття було запроваджене в Індії. У 1971 році в Гонконзі незаконне збагачення («володіння майном незрозумілого походження») було криміналізоване Указом про запобігання хабарництву, який з того часу з успіхом виконується [6, с. 13]. Протягом 20 років після встановлення кримінальної відповідальності за незаконне збагачення в Аргентині та Індії кількість країн, які впровадили аналогічні склади злочину, стрімко зростала і на початок 2020 року їх нараховувалося вже більше 50.

Однак, як показує досвід країн світу, які використовують кримінальну відповідальність за незаконне збагачення, цей захід не є панацеєю у боротьбі з корупцією. Відсутність консенсусу в цьому питанні також підтверджується вказаними міжнародно-правовими документами. Зокрема, у статті 20 Конвенції ООН проти корупції 2003 року і у статті 9 Міжамериканської конвенції проти корупції 1996 року зазначено, що за умови дотримання своєї Конституції та основоположних принципів своєї правової системи держави можуть визнати умисне незаконне збагачення як злочин, а згідно зі статтею 8 Конвенції Африканського союзу про недопущення корупції та боротьбу з нею 2003 року така криміналізація можлива за умови дотримання «положень внутрішнього права» [1, с. 5-6].

Досвід свідчить, що інститут незаконного збагачення спочатку запроваджувався у державах, де на момент його впровадження спостерігався високий рівень корупції та низький рівень доходів громадян, а окремі посадові особи органів державної влади мали величезні статки, які неспівмірні із їхніми офіційними доходами як державних службовців. Варто підкреслити, що нині серед країн, які визнали необхідність запровадження зазначеного інституту, є і держави з досить низьким рівнем корупції (Бельгія, Данія).

Цілком зрозуміло, що в межах цієї статті не можливо проаналізувати усі країни, які мають відповідний досвід, і в цьому, як вбачається, немає необхідності, оскільки в законодавстві бага- 
тьох держав можна знайти спільні риси у питанні, яке нас цікавить. Тому необхідним, на нашу думку, є розгляд положень законодавства тих країн, які дають змогу усвідомити чітку різницю у підходах до розв'язання вказаної проблеми.

Розглядаючи досвід держав, які ратифікували Конвенцію ООН проти корупції, насамперед вважаємо, що їх можна поділити на дві групи: ті, що встановили окрему відповідальність безпосередньо за незаконне збагачення, i ті, які цього не зробили. У першій групі необхідно звернути увагу на те, що законодавство цих держав по-різному визначає диспозиції відповідної статті, що свідчить про відмінності в розумінні змісту поняття «незаконне збагачення».

Литовська Республіка. Кримінальна відповідальність за незаконне збагачення у цій країні була введена до Кримінального кодексу (стаття 189¹) 2010 року: «Особа, якій належить право власності на майно, вартість якого перевищує 500 мінімальних прожиткових мінімумів (приблизно 19000 євро) і яка усвідомлює або мала чи могла усвідомлювати, що таке майно не могло бути придбане з використанням законного доходу, карається штрафом, або арештом, або позбавленням волі на строк до чотирьох років. Особа, яка приймає майно, зазначене в частині 1 цієї статті, від третіх сторін, звільняється від кримінальної відповідальності за незаконне збагачення, якщо він / вона повідомить про це правоохоронні органи до того, як йому / їй буде вручено повідомлення про підозру і якщо він / вона активно співпрацюють у визначенні походження майна» .

Таке майно підлягає обов'язковій конфіскації. Якщо вартість майна менша за встановлене мінімальне значення, то особа мусить сплатити податки на активи й може бути покарана в адміністративному порядку штрафом у розмірі від 10 до $50 \%$ від вартості майна. Згідно зі статтею 190 КК, законний дохід, зазначений у статті $189^{1}$, означає дохід, одержаний від діяльності, не забороненої законодавчими актами, незалежно від того, обліковується він чи ні в порядку, встановленому законодавчими актами [6, с. 13-14].

Криміналізація незаконного збагачення представляє новий правовий інструмент для правоохоронних органів Литви, який був значною мірою заснований на вимогах Конвенції ООН проти корупції, що передбачає здійснення такого правового заходу. Хоча Конвенція була важливим фактором створення підстав для вказаних розробок, необхідність розширення сфери застосування конфіскації майна і конфіскації незаконно набутих активів були рушійною силою політичної волі підтримати поправки до Кримінального кодексу. Однак новий злочин щодо незаконного збагачення представляє значні труднощі для слідчих органів із прокуратурою, а також судів [7].
У цьому випадку необхідно звернути увагу на те, що, на відміну від України, де Конституційний Суд у рішенні від 26.02.2019 № 1-p/2019 визнав норму статті $368^{2}$ «Незаконне збагачення» неконституційною, рішенням Конституційного Суду Литовської Республіки статтю про незаконне збагачення було визнано такою, що відповідає конституції цієї держави, а також здійснено обгрунтований аналіз їі на відповідність принципам верховенства права і презумпції невинуватості [8, с. 13].

Королівство Данія. Ця країна вже не один рік поспіль очолює рейтинг країн світу, що укладається організацією Transparency International і визнається поряд із Фінляндською Республікою та Королівством Швеції країною із найнижчим рівнем корупції [9]. Безпосередньо кримінальна відповідальність за незаконне збагачення в Данії передбачена статтею 144 КК Данії, відповідно до якої будьяка особа, яка при виконанні обов'язків данської державної служби, іноземної держави або міжнародної організації незаконно отримує, вимагає або приймає обіцянку подарунка чи інші привілеї, карається позбавленням волі на будь-який термін, що не перевищує шести років, або, за пом'якшуючих обставин, покаранням у виді штрафу [10].

Королівство Бельгія. Кримінально-правова боротьба з корупцією тут є одним із державних пріоритетів, визначених у «Національному плані з безпеки». Законом «Про боротьбу з корупцією» до Кримінального та Податкового кодексів Бельгії внесено положення щодо протидії незаконному збагаченню, які передбачають, у тому числі, і кримінальну відповідальність за невідповідність придбаного майна офіційним щорічно декларованим доходам [10]. Таким чином, приєднання Бельгії до Конвенції у 2007 році не потягло за собою жодних доповнень чи змін до національного законодавства для реалізації статті 20 Конвенції [11]. Вказане пояснюється тим, що на момент ратифікації законодавство Бельгії вже мало кримінально-правову основу для боротьби з незаконним збагаченням.

Республіка Молдова. У Кримінальному кодексі Молдови окрема норма про кримінальну відповідальність за незаконне збагачення була передбачена лише у 2014 році. Зокрема, зазначено, що «володіння посадовою чи публічною особою особисто або через третіх осіб майном, вартість якого істотно перевищує отримані нею кошти і щодо якої встановлено на підставі доказів, що воно не могло бути отримане законним шляхом, карається штрафом в розмірі від 6000 до 8000 умовних одиниць або позбавленням волі на строк від 3 до 7 років з позбавленням в обох випадках права обіймати певні посади чи займатися певною діяльністю на строк від 10 до 15 років», а «те саме діяння, вчинене особою, яка обіймає відповідальну державну посаду, - штрафом у розмірі від 8000 до 10000 умовних одиниць або позбавленням волі 
на строк від 7 до 15 років з позбавленням в обох випадках права обіймати певні посади чи займатися певною діяльністю на строк від 10 до 15 років» (стаття $330^{2}$ КК Республіки Молдова) [8, с. 12].

Китайська Народна Республіка. Боротьба 3 корупцією була й залишається відкритим пріоритетом уряду Китаю з самого його утворення [12]. Одним із найголовніших органів у боротьбі з корупцією в Китаї є прокуратура. У 1993 році Верховна народна прокуратура КНР підкреслила значення розслідування і судового переслідування випадків великої кількості непоясненого збагачення чиновників. Кримінальна відповідальність за незаконне збагачення пізніше була включена до Кримінального кодексу 1997 року [13].

КК КНР передбачає кримінальну відповідальність за незаконне збагачення у статті 395: «Якщо державні службовці, вартість майна яких чи витрати яких значно перевищують величину законних доходів і це перевищення становить значну суму, можуть бути зобов'язані пояснити джерело доходів. При неможливості підтвердження законності доходів, сума, яка складає різницю, вважається незаконно отриманою. В цьому випадку застосовується покарання у виді позбавлення волі на строк до 5 років чи короткострокового арешту, або, якщо ця різниця дуже велика, винна особа повинна бути засуджена до фіксованого тюремного ув'язнення на термін не менше 5 років, але не більше ніж на 10 років, а надлишок майна підлягає конфіскації» [14, с. 265].

Слід зазначити, що з 2009 року стаття $395 \mathrm{KK}$ зазнала певних змін, а саме була посилена відповідальність державних службовців за незаконне збагачення - збільшено тюремне ув'язнення із 5 до 10 років [15]. Таким чином, держава висловила свою підтримку щодо введення більш суворого покарання за незаконне збагачення, що підтверджує її активну позицію у боротьбі з корупційними виявами. Крім того, частина друга статті 395 КК КНР передбачає кримінальну відповідальність за незаявлену державним службовцем крупну суму грошей, яка міститься на рахунках за кордоном [15; 16].

Аргентинська Республіка. Разом 3 Індією Аргентина стала однією 3 перших країн, які у 1964 році криміналізували незаконне збагачення. Частина 2 статті 268 КК Аргентини 1964 року передбачає: «Будь-яка особа, яка у відповідь на законну вимогу не надає виправдання походженню значного збагачення себе чи використовуваного нею з метою прикриття третьої особи під час перебування на державній посаді та в період до двох років після припинення виконання своїх обов'язків, карається позбавленням волі на строк від двох до шести років, штрафом у розмірі від 50 до $100 \%$ суми збагачення і довічною абсолютною поразкою у правах. Під збагаченням розуміється не лише збільшення статків особи грішми, речами чи товарами, а й скасування її заборгованості чи погашення зобов'язань. Особа, яка використовувалася як прикриття з метою приховування збагачення, карається так само, як і винна в злочині особа» [6, с. 13].

До першої групи держав відносимо й Україну, оскільки статтею $368^{5}$ КК України запроваджено кримінальну відповідальність за незаконне збагачення. Порівнюючи їі з іншими країнами першої групи, загалом можна зазначити, що законодавець. визначивши в диспозиції статті незаконними активи, вартість яких більше ніж на 6500 неоподатковуваних мінімумів доходів громадян перевищує її законні доходи (стаття $368^{5}$ КК України), обрав один із варіантів, який існує в зарубіжних країнах. Водночас відмінністю є те, що в нашій державі незаконним збагаченням $€$ саме «набуття» цих активів - термін, який не використовується в жодній із зарубіжних країн.

Іншу групу становлять країни, що відмовилися від встановлення окремої відповідальності за незаконне збагачення.

Французька Республіка. Досліджуючи французьке антикорупційне законодавство, необхідно зазначити, що Франція стала першою країною «Групи сімки», яка ратифікувала Конвенцію, хоча і не ввела окремого складу злочину «незаконне збагачення». Французький законодавець керувався тим, що Конвенція не досить чітко формулює поняття «незаконне збагачення», оскільки сам по собі факт володіння майном не є кримінально караним злочином. Тому кримінальну справу у французькій юридичній практиці порушують лише в тому випадку, якщо є підстави вважати, що активи публічної посадової особи (або приватної особи - французьке законодавство не робить у такому випадку розмежування) отримані незаконним шляхом. Як важливі підстави можуть бути використані непрямі ознаки наявності протиправних дій не лише з боку підозрюваної особи, а й членів її родини (наприклад, способу життя, даних податкової та антикорупційної декларацій як самого службовця, так і членів його родини тощо) [18].

Відповідно до статті $321^{6}$ Кримінального кодексу Франції нездатність особи обгрунтувати джерела доходів, що відповідають її способу життя, якщо така особа має законну владу над неповнолітнім, який проживає разом з нею і систематично скоює злочини або проступки проти майна інших осіб, карається 5 роками тюремного ув'язнення і штрафом у розмірі 375000 євро. Штраф може бути призначений на суму понад 375000 євро аж до половини вартості прихованого майна. За статтею 450-2-1 нездатність особи обгрунтувати джерела доходів, відповідних її способу життя, якщо вона підтримує регулярні зносини з особами, які займаються діяльністю, визначеною стат- 
тею $450^{1}$ «Організація зловмисників», карається 5 роками тюремного ув'язнення і штрафом в розмipi 375000 євро [6, с. 16].

Великобританія. Попри те, що Великобританія ратифікувала Конвенцію ООН проти корупції 09 лютого 2006 року [19], незаконне збагачення як злочин не було введено в британське законодавство. Причиною цьому стало побоювання, що його положення щодо скасування тягара доведення, а також відсутність необхідності продемонструвати зв'язок між активами і злочинною діяльності не відповідає принципам належної правової процедури [20]. Transparency International у Beликобританії на сьогодні запропонував додати до національного законодавства такий інститут як «Незрозумілий порядок багатства» (UWO) до інструментів громадянського відновлення доходів від корупції, доступних для правоохоронних органів Великобританії [20].

Федеративна Республіка Німеччина. Ратифікація Німеччиною до Конвенції у 2014 році [19] не потягла за собою жодних доповнень чи змін до національного законодавства для реалізації статті 20. Так, у законодавстві Німеччини немає терміну «незаконне збагачення», так само як і не передбачається відповідальності за такий злочин. Водночас тут існує поняття «безпідставне збагачення», яке широко використовується в податковому та цивільному законодавстві [21].

Пункт d статті 73 Кримінального кодексу Нiмеччини є тим законодавчим положенням, яке перекладає тягар доказування на обвинуваченого в разі встановлення стороною обвинувачення суттєвого збільшення активів державної посадової особи, що є необгрунтованим. Законодавство встановлює конфіскацію активів «у разі наявності підстав вважати, що ці предмети використовувалися для скоєння незаконних діянь або були одержані шляхом їх скоєння». Федеральний верховний суд дійшов висновку, що таке положення не зменшує тягаря доказування, а звільняє сторону обвинувачення від 3 'ясовування «конкретних деталей» злочину [17, с. 51].

Республіка Ірландія. Тут ситуація дещо відмінна від попередніх країн. Попри те, що $\mathrm{K} \kappa$ не передбачає кримінальної відповідальності за незаконне збагачення, у цій країні в рамках податкового законодавства містяться положення щодо неправомірного збагачення ("unjust enrichment"), яке застосовується у випадках, якщо особа робить неправдиве повідомлення до податкової інспекції про податок на додану вартість, тобто заявляє про більший розмір, ніж було сплачено з метою отримання повернення певної суми з податкової інспекції [22].

3 огляду на відсутність поняття «незаконного збагачення» в ірландському законодавстві, існують законодавчі акти і заходи, визначення і зміст яких схожі зі статтею 20 Конвенції. Крім того, існують положення з приводу запобігання хабарництву, а також встановлена заборона посадовим особам на отримання дарунків певного розміру та корупційного збагачення. Однак важливу юридичну роль відіграють судові процеси, трибунали проти корупції посадових осіб, які створюють правові прецеденти за останні 10 років (Трибунали Моріарті і Мехона) і укази Верховного Суду Ipландії за «заморожування» майна під час процесів про корупцію» [22].

Латвійська Республіка. Аналіз латвійського законодавства показує, що ця країна не встановила окремого злочину за незаконне збагачення [23], хоча Латвія ратифікувала Конвенцію у 2006 році [19]. Наразі дієвою формою контролю за законністю отримання доходів особами, які виконують функції держави, є декларування доходів і видатків держслужбовців і членів їхніх сімей. Вимоги щодо офіційного оприлюднення доходів службовців наявні в багатьох країнах світу, а неподання декларації або подання недостовірних даних карається накладенням штрафу. Наявність у законодавстві Латвійської Республіки інституту декларування доходів і відповідальності за його порушення є дієвим механізмом боротьби з незаконно отриманими активами службовців [4, с. 89].

Королівство Швеція. Ця країна ратифікувала Конвенцію ООН проти корупції у 2007 році [19], однак до цього часу незаконне збагачення тут не криміналізоване. Це пояснюється тим, що КК Королівства Швеції містить низку статей щодо кримінальної відповідальності за відмивання грошей, податкові злочини, зокрема, щодо подання недостовірних відомостей про майно [24].

Португальська Республіка. Уряд, проголосивши широкомасштабну боротьбу корупції, не встановив кримінальну відповідальність за незаконне збагачення [25]. Аналіз пропонованих у різний час законопроєктів показує, що португальський законодавець при спробі сформулювати самостійну статтю кримінального законодавства, присвячену незаконному збагаченню, стикається з труднощами, пов'язаними із забезпеченням дотримання ключового для національного законодавства положення п. 1 ст. 32 конституції Португальської Республіки про гарантії захисту обвинуваченого в кримінальному процесі. Так, специфіка складу статті 20 Конвенції «Доходи, які державна посадова особа не може раціонально обгрунтувати» важко узгоджується з поняттям презумпції невинуватості, тобто правом не вважатися винним до моменту оголошення вироку, покладення тягаря доказування та кримінально-правової конструкції провини [26].

Республіка Польща. Відповідно до Записки Секретаріату Польщі від 13-15 жовтня 2014 року з огляду на хід здійснення імплементації Конвен- 
ції ООН проти корупції уряд, розглянувши можливість криміналізації незаконного збагачення, не встановив окремої норми щодо кримінальної відповідальності за такий злочин. Втім, як боротьба з корупційними злочинами, в тому числі і з незаконним збагачення, застосовується розширена конфіскація [27].

Не встановили в своєму законодавстві окремої відповідальності за незаконне збагачення і СІІА, які ратифікували Конвенцію у 2006 році. Крім цього, США, як і Канада, ратифікувавши задовго до появи Конвенції ООН Міжамериканську конвенцію про боротьбу з корупцією, в тому числі й статтю 9, яка передбачає кримінальну відповідальність за незаконне збагачення, зробили застереження з приводу встановлення кримінальної відповідальності за незаконне збагачення, пославшись на його несумісність із принципами конституційного права та прав людини i, зокрема, презумпцією невинуватості $[17$, с. 23$]$.

у документі USA UNCAC Self Assessment "UNODC - United Nations Convention against Corruption" (07/10/2010) наголошується на тому, що США має достатній внутрішній механізм (національне законодавство, в тому числі і кримінальне) для притягнення до відповідальності державних службовців, які отримують необгрунтовані фінансові вигоди, а також про намір надавати допомогу і співпрацювати з іншими державами-учасницями в сфері протидії корупції [28, с. 81-82]. Сполучені Штати Америки використовують свідчення про незаконне збагачення як докази у кримінальних справах, а незаконне збагачення - як підставу для звільнення корумпованих офіційних осіб з їхніх посад [8, с. 11].

\section{Висновки}

1. Серед зарубіжних країн, які ратифікували Конвенцію ООН про боротьбу з корупцією і запровадили у своєму законодавстві відповідальність безпосередньо за незаконне збагачення, є країни як із високим, так і з низьким рівнем корупції. $\mathrm{У}$ них кримінальна відповідальність за незаконне збагачення розглядається як механізм, здатний доповнити існуючу систему протидії корупції, якою б ефективною вона не була.

2. Серед держав, які ратифікували Конвенцію ООН про боротьбу з корупцією і запровадили у своєму законодавстві кримінальну відповідальність безпосередньо за незаконне збагачення, спостерігається різниця в розумінні того, що саме слід вважати «незаконним збагаченням». Під цим терміном розуміють перевищення певної кількості мінімальних прожиткових мінімумів відносно законного доходу; незаконне отримання, вимагання, приймання обіцянки подарунка або іншої привілеї; невідповідність придбаного майна офіційним, щорічно декларованим доходам; володіння майном, вартість якого істотно пере- вищуе отримані кошти; вартість наявного майна чи витрати значно перевищують величину законних доходів, і посадовець не здатен це пояснити; неможливість державного службовця пояснити законне збільшення його активів або законність джерела його доходів.

3. Законодавець, визначивши в диспозиції статті $368^{5}$ Кримінального кодексу України незаконне збагачення як набуття особою, уповноваженою на виконання функцій держави або місцевого самоврядування активів, вартість яких більше ніж на 6500 неоподатковуваних мінімумів доходів громадян перевищує її законні доходи, обрав один із варіантів, який існує в зарубіжних країнах. Водночас відмінною рисою $€$ те, що в нашій державі незаконним збагаченням $е$ саме "набуття» цих активів - термін, який не використовується в жодній із зарубіжних країн.

4. Група країн, які вирішили не встановлювати окремо кримінальну відповідальність за незаконне збагачення державних посадових осіб, часто пояснюючи це суперечливістю принципу презумпції невинуватості або ж недостатньою чіткістю формулювання поняття «незаконне збагачення» в Конвенції ООН проти корупції, запровадили альтернативні засоби боротьби з незаконним збагаченням на кшталт заходів, які спрощують кримінальне переслідування правопорушників або конфіскацію незаконної наживи. Такі правові диспозиції здебільшого спираються на положення законодавства з питань боротьби з організованою злочинністю, яке подекуди зменшує тягар доведення вини для сторони обвинувачення або частково переносить цей тягар на сторону захисту.

5. Окремі з країн, які вирішили не встановлювати кримінальну відповідальність за незаконне збагачення державних посадових осіб, використовують терміни «безпідставне збагачення» або «неправомірне збагачення» у своєму податковому та цивільному законодавстві.

\section{Jimepamypa}

1. Шевчук С.В. Окрема думка судді Конституційного суду Шевчука С.В. у справі за конституційним поданням 59 народних депутатів України щодо відповідності Конституції України (конституційності) статті 368-2 Кримінального кодексу України. URL: http://www. ccu.gov.ua/sites/default/files/docs/1_p_2019_7_0.pdf.

2. Міжамериканська конвенція проти корупції. URL: https://zakon.rada.gov.ua/laws/show/998_089.

3. Інформаційна довідка щодо держав, які підписали та ратифікували Міжамериканську конвенцію проти корупціï. URL: http://www.oas.org/juridico/ english/Sigs/b-58.html.

4. Гарбазей Д.О. Незаконне збагачення: міжнародно-правовий аспект. / Д.О. Гарбазей. Київ : Альманах міжнародного права. Випуск 4. С. 84-94.

5. Конвенція Організації Об'єднаних Націй проти корупції від 31.10.2003, ратифікована Верховною $\mathrm{Pa}$ дою України 18.10.2006. URL: https://zakon.rada.gov. ua/laws/show/995_c16. 
6. Висновок amicus curiae наданий Делегацією Європейського Союзу в Україні та Консультативною місією Європейського Союзу в Україні згідно з частиною 3 статті Закону України «Про конституційний суд України» щодо відповідності Конституції України статті 368-2 Кримінального кодексу України. URL: https://euaci.eu/assets/userfiles/resources/AMICUS\% 20CURIAE $\% 20$ BRIEF very $\% 20$ final $\% 20$ Ukr.pdf.

7. Laurynas Pakstaitis. Neteisetas praturtejimas kaip nusikalstama veika: istakos, kriminalizavimo problema, taikymas, perspektyvos // Jurisprudence a. 2013, 20 (1): C. 319-341. URL: https://www.mruni.eu/upload/iblock/ ef9/018_Pakstaitis.pdf.

8. Сліденко І.Д. Окрема думка судді Конституційного суду Сліденка І.Д. у справі за конституційним поданням 59 народних депутатів України щодо відповідності Конституції України (конституційності) статті 368-2 Кримінального кодексу України. URL: http://www. ccu.gov.ua/sites/default/files/docs/1_p_2019_8_0.pdf.

9. Excerpts from Danish Legislation / Criminal Law Denmark. URL: https://www.oecd.org/daf/antibribery/anti-briberyconvention/37472519.pdf.

10. Спеціалізовані інституції з боротьби проти корупції: огляд моделей. URL: https://www.oecd.org/ corruption/acn/39972270.pdf.

11. Das belgische Strafgesetzbuch (Кримінальний кодекс Бельгіï). URL: https://books.google.com.ua/ books/about/Das belgische Strafgesetzbuch. $\mathrm{html}$ ?id=0S8jAAAAQBBAJ\&redir $\overline{\mathrm{esc}}=\mathrm{y}$.

12. Yong Guo, Political Culture, Administrative System Reform and Anticorruption in China: Taking the Official Car Management Institution Reform as an Example, 53 CRIME L. \& SOC. CHANGE 493, 499 (2010). (Ян Го. Політична культура, система адміністративноїреформи та боротьба з корупцією в Китаї: Беручи за приклад реформу державного управління. Злочин, закон соиіальні зліни (2010). № 53. С. 493-508). URL: http:/ ir.nsfc.gov.cn/paperDownload/1000002198330.pdf.

13. Olivia Yu. Corruption in China's economic reform: a review of recent observations and explanations. URL: https://www.researchgate.net/publication/225695674 Corruption in_China's_economic_reform_A_review of recent observations and explanations.

14. Коробеев А.И., пер. с китайського Вичикова Д.В. Уголовный кодекс Китайской Народной Республики. СПб : Издательство «Юридический центр Пресс», 2001. 303c.

15. Criminal Law of the People's Republic of China. URL: http://www.fmprc.gov.cn/ce/cgvienna/eng/dbtyw/jdwt/crimelaw/t209043.htm.

16. Margaret $K$. Lewis. Presuming Innocence, or Corruption, in China. URL: https://law.shu.edu/ faculty/full-time/margaret-lewis.cfm.

17. Лінді Музіла, Мішель Моралес, Маріанне Матіас, Тамар Берґер. Хабарники. Встановлення кримінальної відповідальності за незаконне збагачення як засіб протидії корупції. URL: http://documents. worldbank.org/curated/en/736961500922443516/pdf.

18. Международные механизмы противодействия коррупции. Информационно-аналитический обзор. URL: http://crimecor.rada.gov.ua/uploads/documents/ 29867.pdf.

19. United Nations Convention against Corruption Signature and Ratification Status as of 6 February 2020. URL: https://www.unodc.org/unodc/en/corruption/ ratification-status.html.

20. Introducing illicit enrichment in the UK: a proposal by Transparency International UK. URL: https://www.lexology.com/library/detail.aspx?g= 9b5b6eca-26a2-4362-90c8-286712eefe43.
21. David A Juentgen. Unjustified enrichment in New Zealand and German law. URL: http://www.nzlii.org/ nz/journals/CanterLawRw/2002/12.html.

22. Andrew Tettenborn. Law of Restitution in England \& Ireland. URL: https://books.google.com.ua/ books?id=LfR4ZqlVocIC\&printsec $=$ frontcover $\& \mathrm{hl}=\mathrm{ru} \&$ source $=g b s \_g e \_s u m m a r y \_r \& c a d=0 \# v=$ onepage $\& q \& f=f$ alse.

23. Criminal Law of the Republic of Latvia (1998, amended 2018). URL: https://www.legislationline.org/ download/id/8266/file/Latvia_CC_1998_am2018_ en.pdf.

24. The Swedish Penal Code. URL: https://www. regeringen.se/49bb67/contentassets/72026f30527d401 89d74aca6690a35d0/the-swedish-penal-code.

25. Codigo Penal Portugues. URL: http://www. pgdlisboa.pt/leis/lei_mostra_articulado.php?nid= 109\&tabela=leis.

26. Constituição da República Portuguesa. URL: https://www.parlamento.pt/Legislacao/paginas/ constituicaorepublicaportuguesa.aspx.

27. Implementation Review Group Resumed Fifth session Vienna, 13-150ctober2014Agendaitem2Review of implementation of the United Nations Convention against Corruption. URL: https://www.unodc.org/unodc/en/ corruption/IRG/implementation-review-group.html.

28. Гузоватий O.I., Титаренко О.О. Кримінальна відповідальність за незаконне збагачення в Україні та деяких зарубіжних країнах : Монографія / O.І. Гузоватий, 0.О. Титаренко. Дніпро : Дніпроп. держ. ун-т внутр. справ, 2018. 260с.

\section{Анотація}

Юрчишин І. Б. Кримінальна відповідальність за незаконне збагачення: зарубіжний досвід правової регламентації. - Стаття.

Стаття присвячена дослідженню особливостей правової регламентації кримінальної відповідальності за незаконне збагачення в деяких зарубіжних країнах та їх порівнянню 3 відповідними положеннями законодавства України. Автор, розглядаючи положення міжнародних правових актів, що закріплюють загальні засади юридичної відповідальності за незаконне збагачення, а також норми національного законодавства різних зарубіжних країн, здійснює ïx порівняльний аналіз, в результаті чого виокремлює спільні риси та особливості.

Наголошується на необхідності проведення наукових досліджень інституту кримінальної відповідальності за незаконне збагачення як складника комплексного підходу до розв'язання вказаної проблеми та вивчення зарубіжного досвіду в контексті таких досліджень. Підкреслюється, що питанню протидії незаконному збагаченню як окремому злочину у значній частині країн світу почали приділяти увагу саме з моменту прийняття Конвенції ООН проти корупції. Водночас держави, які ратифікували Конвенцію, по-різному протидіють цьому злочину, у зв'язку з чим автор поділяє їх на дві групи: ті, що встановили окрему відповідальність безпосередньо за незаконне збагачення, i ті, які цього не зробили.

Досліджуючи країни першої групи, автор наголошує, що до неї входять держави як із високим, так і з низьким рівнем корупції, що свідчить про те, що відповідальність за незаконне збагачення розглядається як механізм, який здатний доповнити існуючу систему протидії корупції, якою б ефективною вона не була. Звертається увага на відмінності в розумінні змісту поняття «незаконне збагачення» у законодавстві цих дер- 
жав. Дослідження законодавства держав другої групи дає змогу зрозуміти, у зв'язку з чим вони відмовилися встановлювати окрему відповідальність за незаконне збагачення i які альтернативні засоби застосовують у протидії цьому злочину.

Окремі з цих країн використовують терміни «безпідставне збагачення» або "неправомірне збагачення» у своєму податковому та цивільному законодавстві. Підкреслюється, що Україна як держава, яка відноситься до першої групи, обравши один із варіантів диспозиції відповідної статті Кримінального кодексу, який існує в зарубіжних країнах, закріпила термін «набуття активів», що в інших країнах не використовується. Наприкінці статті автор робить низку висновків, яких він дійшов у результаті дослідження.

Ключові слова: незаконне збагачення, кримінальна відповідальність, боротьба з корупцією, правова регламентація, Конвенція ООН проти корупції, державна посадова особа.

\section{Summary}

Yurchyshyn I. B. Criminal liability for illicit enrichment: foreign experience of legal regulations. Article.

This article is consecrated to investigation of the peculiarities of the legal regulation of criminal liability for illicit enrichment in some foreign countries and their comparison with the legislation of Ukraine. The author is considering the position of international legal acts which fix common general principles of legal liability for illicit enrichment and also the rules of national law of various foreign countries, implement a comparative analysis that resulting in common features and characteristics.

The necessity of research institute criminal liability for illegal enrichment as part of a comprehensive ap- proximation to resolve the above-mentioned problem and study international experience in the context of such research. It is emphasized that the issue of combating illegal enrichment as a separate crime in many parts of the world began to pay attention since the acceptance of the UN Convention against Corruption. Meanwhile, countries that have ratified the Convention oppose this crime in different ways, therefore, the author divides them into two groups - those that made a specific accountability directly on illicit enrichment and those that did not.

Exploring the country's of first group, the author emphasizes that it includes the state as high and low levels of corruption, which indicates that responsibility for illicit enrichment is seen as a mechanism that can supplement the existing system of combating corruption, no matter how effective it is. Attention is paid to the differences in the understanding of what constitutes "illicit enrichment" in the legislation of these countries. The research of the laws of the second group provides us with an opportunity to understand and therefore they recite to establish a separate liability for illegal enrichment and use that alternative means of struggling this crime.

Also, some of these countries use the expression "unjust enrichment" or "illegal enrichment" in their tax and civil legislation. It is emphasized that Ukraine, as a country which belonging to the first group, choosing one of the options for the disposition of the pertinent article of the Criminal Code which exists in foreign countries, intensified, while the term "acquisition of assets", which in other countries is not used. At the end the author makes a number of conclusions which he came to as a result of research.

Key words: illicit enrichment, criminal responsibility, fight against corruption, legal regulation, the UN Convention against Corruption, public official. 